\title{
Innovaatiot aluekehittämisessä - uutta paradigmaa etsimässä
}

Mustikkamäki, Nina ja Sotarauta, Markku (toim.) (2008). Innovaatioympäristön monet kasvot. Tampere: Tampereen Yliopistopaino Oy. 363 sivua.

\section{$\mathrm{S}$} uomen kaupunkiseutujen kehittämisessä on pitkään annettu suuri paino osaamiselle ja innovaatioille. Esimerkki innovaatiolähtöisestä aluekehittämisestä on Valtioneuvoston 1990-luvun puolivälissä alulle panema kansallinen osaamiskeskusohjelma. Ohjelmassa eri kaupunkiseuduilta tunnistettiin lähinnä yliopistojen ja yrityksien muodostamia osaamisen klustereita, joista parhaimmillaan muodostui aluetalouden vetureita. Tampereen, Jyväskylän ja Oulun seutujen rakennemuutos, nopea talouskasvu ja kansainvälistyminen ovat näkyvimpiä esimerkkejä, mutta menestyksiä on ollut lukuisia muitakin.

Nyt vanhat eväät on syöty. Tutkijoiden ja kehittäjien näkemys innovaatioiden luonteesta yleensä ja innovaatiotoiminnan sidoksesta paikkoihin ja alueisiin erityisesti on muuttumassa. Tampereen yliopiston Alueellisen kehittämisen tutkimusyksikön (Sente) tutkijoiden kirjoittama Innovaatioympäristön monet kasvot valottaa näitä muutoksia rikkaalla tavalla. Kirjan artikkelit etsivät uuden teorian ja muutamien empiiristen tutkimusten kautta tuoreita suuntia käytännön aluekehittämiselle.

Mihin kirjoittajien mukaan ollaan menossa? Mihin aluekehittämisen voimia pitäisi nyt suunnata? Vastaus ei ole aivan yksi- selitteinen, sillä eri kirjoittajien painotukset vaihtelevat. Tietty yhteinen näkemys on kuitenkin selvä: Ensiksi, innovaatioiden yhteyttä tieteelliseen tutkimukseen on vahvasti liioiteltu. Keksintöjä ja pieniä parannuksia, jotka sovellettuina tuottavat taloudellista lisäarvoa, syntyy hyvin paljon käytännön työssä yrityksissä, julkisessa hallinnossa ja kolmannella sektorilla. Toiseksi, innovaatiotoiminnan vahva paikallinen sidos, ajatus kaupunkiseudun "innovatiivisesta miljööstä”, on syytä haastaa. Paikallinen "pörinä" ei toimi ilman "globaaleja kanavia" (Bathelt ym. 2002), ja myös niin sanottu hiljainen tieto, jonka on ajateltu selittävän innovaatioverkostojen paikallisuutta, liikkuu asiantuntijavierailuiden, konsultoinnin ja työpaikkaa vaihtavien mukana. Kolmanneksi, strateginen, päämäärätietoinen kehittäminen ei riitä, vaan nopeasti muuttuvassa ja epäselvässä ympäristössä oleellisinta on alueiden itseuudistumisen kapasiteetti ja siihen liittyvät institutionaalinen yrittäjyys ja yksilöiden välittäjäroolit. Jos tutkimuksen ja kehittämisen vakiintunutta sanastoa ovat tähän asti olleet kilpailukyky, innovaatiojärjestelmä, teollinen klusteri ja oppiva alue, Innovaatioympäristön monet kasvot tuo mukaan evoluutionäärisen tutkimusotteen, systee- misen muutoksen, käyttäjät ja avoimen innovaation.

Kirjan tarjoamista monista erinomaisista ajatuspoluista haluan nostaa esille Vesa Harmaakorven (Käytäntölähtöisen innovaatiotoiminnan ympäristöt, s. 108) ja Nina Mustikkamäen (Välittäjät bioteknologia-alalla, s. 266) artikkeleissaan kehittelemän sosiaalisten verkostojen innovaatiopotentiaalin tulkinnan. Lähtökohtana on Granovetterin (1973) klassinen erottelu sosiaalisten verkostojen heikoista ja vahvoista sidoksista. Harmaakorpi toteaa, että innovaatioiden synnyn kannalta vahvat sidokset ovat helpompia, koska niihin liittyy osapuolten välinen luottamus, yhteiset päämäärät ja kieli. Toisaalta henkilöt, joiden välillä on vahva, vastavuoroinen sosiaalinen sidos, todennäköisesti jo tietävät samat asiat, mikä estää uudenlaisten tietojen luovan yhdistämisen ja siihen perustuvan innovaatioprosessin. Innovaatiot syntyvät pikemminkin vahvojen sidosten luonnehtimien homogeenisten verkostojen välimaastossa, ns. rakenteellisissa aukoissa (Burt 2004).

Mustikkamäki konkretisoi ideaa mainiossa organisaatioteoriaan ja verkostojen tutkimukseen pohjaavassa artikkelissaan. Hän on löytänyt bioalalta (empiria on Tampereen seudulta) lukuisia rakenteellisissa aukoissa toimivia välittäjätyyppejä ja -rooleja, jotka aivan oleellisella tavalla parantavat organisaatioidensa oppimiskykyä. Näitä rooleja ovat 
"välittäjä”, ”tulkki”, ,kkutoja” ja "näkijä" (s. 284).

Juha Kostiainen (Kaupunkiseutujen innovaatiopolitiikka ja itseuudistuminen, s. 132) puolestaan pureutuu kaupunkiseutujen muutokseen evoluutionäärisestä ja systeeminäkökulmasta. Charles Darwinin juhlavuonna voi arvostaa sitä, että uusdarwinistiset analogiat ovat monilla aloilla, myös kaupunkitalouden tutkimuksessa, käypää tavaraa. Artikkelissaan Kostiainen kuitenkin oikein toteaa, että kompleksisuus (Prigogine ja Stengers 1984) on darwinismia hedelmällisempi evolutionäärisen aluetutkimuksen kehys. Tätä kautta päästään dynaamisiin systeemeihin ja niiden emergentteihin piirteisiin, joihin lukeutuu myös mainittu itseuudistumisen kapasiteetti (Sotarauta 2005). Kostiaisen mukaan itseuudistumista voidaan käytännössä vahvistaa luomalla uudentyyppisiä kehitysalustoja (test bedit ja living labit), painottamalla julkisissa hankinnoissa hinnan lisäksi sisällöllistä kehittämistä ja tuottajan innovaatioita sekä lisäämällä aitoa osallistumista. Parhaimmillaan voidaan päästä "neloskierteeseen", jossa kehittäjät, käyttäjät, hyödyntäjät ja mahdollistajat (esimerkiksi yliopisto, asukkaat, yritykset ja kaupunki) toimivat yhdessä avoimessa innovaatioprosessissa.

Nämä kaksi nostoa kuvaavat artikkelikokoelman luonnetta. Kirja on teoriapitoinen ja moninäkökulmainen. Artikkelit linkittyvät toisiinsa etenkin yhteisen teoriapohjan kautta, ja tekstien yhteydet ja limittymiset tarjoavat lukijalle oivalluksia. Innovaatiotoiminnan ja alueellisen kehittämisen rakenteet ja instituutiot toisaalta ja aktiiviset, taitavat yksilöt pyrkimyksineen toisaal- ta ovat dialektisessa suhteessa.

Vaikka näkemys Suomen aluekehittämisen uusista haasteista suodattuu esiin vaihtelevissa muodoissa useista teksteistä, keskeisenä ideana toistuu tarve siirtyä mekanististisesta, tiede- ja teknologiapainotteisesta innovaatiojärjestelmän ideasta (tiedon tuotto, tiedon käyttö) kohti emergenttien, yllättävien kehityskulkujen ja strategisen kehittämisotteen välillä tasapainoilevaa ja avoimeen (palvelu) innovaatioon nojaavaa, itseuudistuvaa järjestelmää (yhteenkietoutunut moninaisuus, innovaatioekologia). Tekijöiden kunniaksi on sanottava se, että julkaisemisen jälkeen alkanut globaali lama ei ole vanhentanut kirjan ideoita. Systeemisyys, instituutioiden muutos ja alueiden moninaisuudesta syntyvä resilienssi eli sitkeys ovat juuri nyt ajankohtaisia teemoja.

Moninaisuudessaan kirja on kiinnostava puheenvuoro, sillä Sente on sekä muovannut kansallista politiikkaa että osallistunut aktiivisesti etenkin läntisen Suomen kaupunkiseutujen kehittämiseen. Useat Senten tutkijat ovat toimineet kaupunkien virkamiehinä ja yritysten kehittämistehtävissä: yksikkö on itse osa analysoimiaan innovaatioverkostoja. Tämä ei ole ongelma, päinvastoin. Kirjoittajien näkökulma on asiantunteva, mutta paikoin lukijaa vaivaa tietty sisäpiirimäisyys. Tutkijan kriittinen puhe ja kehittäjän innostava puhe menevät muutamassa kohdassa sekaisin. Kyse on tyylistä, sillä asiat ovat kirjassa kohdallaan.

- Kaksi kehittämisehdotusta sallittaneen. Osittain samoja lähteitä käyttävää ja samoja keskusteluja referoivaa artikkelikokoelmaa vaivaa toisto, sitä ei voi ko-

konaan välttää. Ongelmaa olisi vähentänyt yhteinen kirjallisuusluettelo ja tärkeimmät käsitteet ja lähteet kattava indeksi.

Innovaatioympäristön monet kasvot juhlistaa Alueellisen kehittämisen tutkimusyksikön 10vuotista taivalta. Pienistä puutteista huolimatta se on suositeltavaa luettavaa oppimisen- ja organisaationtutkijoille, aluekehittäjille ja suunnittelijoille. Onnittelut hyvästä kirjasta Sentelle ja kirjoittajakunnalle!

\section{Viitteet}

Bathelt, H., Malmberg, A., Maskell, P. (2002). Clusters and Knowledge: Local Buzz, Global Pipelines and the Process of Knowledge Creation. DRUID Working Papers No. 02-12.

Burt, R. (2004). Structural Holes and Good Ideas. American Journal of Sociology. Vol. 110, No. 2, ss. 349-399.

Granovetter, M. S. (1973). The strength of weak ties. American Journal of Sociology. Vol. 78, ss. 1360-1380.

Prigogine I. ja Stengers I. (1984). Order out of Chaos. Man's Dialogue with Nature. New York: Bantam.

Sotarauta, M. (2005). Resilient city-regions - mission impossible? Observatory Pascal. Place Management, Social Capital and Lifelong Learning. <www.obspascal.com/resources/markkusotarautaaugust2005. pdf>

\section{Panu Lehtovuori}

